\title{
LEGIB
}

A major purpose of the Technical Information Center is to provide the broadest dissemination possible of information contained in DOE's Research and Development Reports to business, industry, the academic community, and federal, state and local governments.

Although a small portion of this report is not reproducible, it is being made available to expedite the availability of information on the research discussed herein. 


\title{
HEALTH AND SAFETY RESEARCH DIVISION
}

Waste Management Research and Development Programs (Activity No. AH 100500 0; NEAH001)

\section{RESULTS OF THE RADIOLOGICAL SURVEY AT 19 REDSTONE LANE, LODI, NEW JERSEY}

(J056)

W. D. Cottrell, L. M. Floyd, M. W. Francis, and J. O. Mynatt

\author{
Date Published - October 1989
}

\section{Investigation Team}

R. E. Swaja - Measurement Applicatinns and Development Manager

W. D. Cottrell - Project Director

R. W. Doane* - Field Survey Supervisor

Survey Team Members

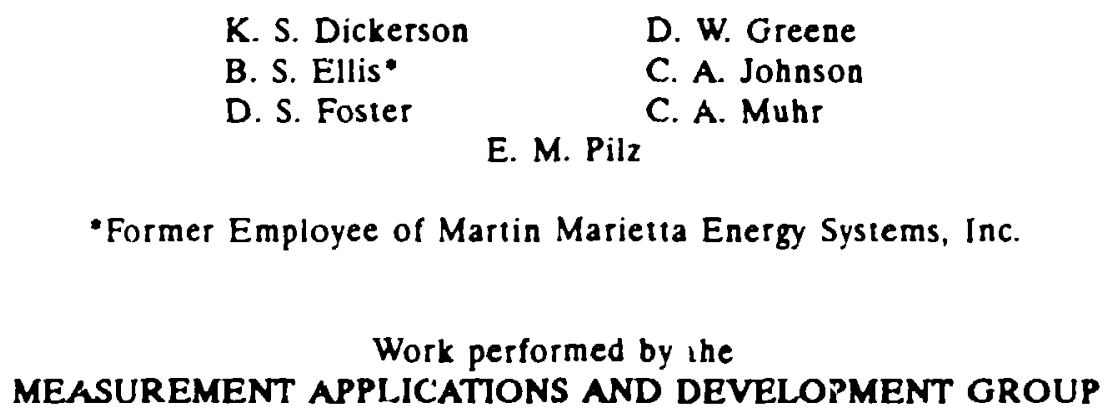

- Former Employee of Martin Marietta Energy Systems, Inc.

Work performed by the MEASUREMENT APPLICATTONS AND DEVELOPMENT GROUP 


\section{CONTENTS}

LIST OF FIGURES $\ldots \ldots \ldots \ldots \ldots \ldots \ldots \ldots \ldots \ldots \ldots$

LIST OF TABLES $\ldots \ldots \ldots \ldots \ldots \ldots \ldots \ldots \ldots \ldots \ldots$ vii

ACKNOWLEDGMEN $\mathrm{rS} \ldots \ldots \ldots \ldots \ldots \ldots \ldots \ldots \ldots \ldots$ ix

ABSTRACT $\ldots \ldots \ldots \ldots \ldots \ldots \ldots \ldots \ldots \ldots \ldots \ldots \ldots$

INTRODUCTION $\ldots \ldots \ldots \ldots \ldots \ldots \ldots \ldots \ldots \ldots \ldots \ldots \ldots \ldots$

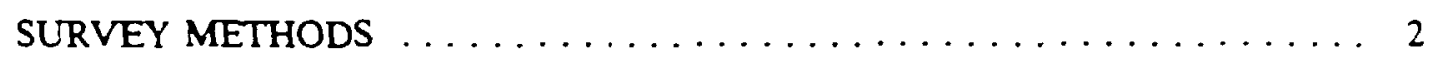

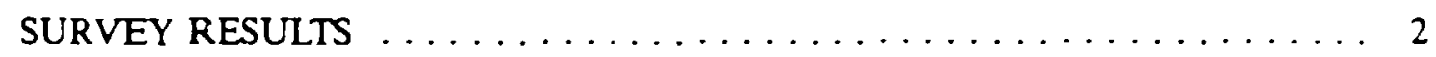

Surface Gamma Radiation Levels . . . . . . . . . . . . . . . 2

Systematic Soil Samples . . . . . . . . . . . . . . . . . 3

Auger Hole Soil Samples and Gamma Logging . . . . . . . . . . . . . 3

SIGNIFICANCE OF FINDINGS $\ldots \ldots \ldots \ldots \ldots \ldots \ldots \ldots \ldots$

REFERENCES $\ldots \ldots \ldots \ldots \ldots \ldots \ldots \ldots \ldots \ldots \ldots \ldots \ldots \ldots \ldots$ 


\section{LIST OF FIGURES}

1 Gamma radiation levels $(\mathrm{P} / \mathrm{h})$ measured on the surface at 19 Redstone Lane, Lodi, New Jersey $(\mathrm{LJ} 056) \ldots \ldots \ldots \ldots \ldots \ldots \ldots \ldots \ldots$

2 Diagram showing locations of soil samples taken at 19 Redstone Lane, Lodi. New

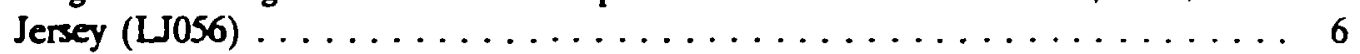

3 Gamma profile for auger hole 1 (L056A1) at 19 Reditone Lane, Lodi, New Jersey . . . . . . . . . . . . . . . . . . . . . . . . .

4 Gamma profile for auger hole 2 .LJ056A2) at 19 Redstone Lane, Lodi, New Jersey . . . . . . . . . . . . . . . . . . . . . 8 


\section{LIST OF TABLES}

1 Applicable guidelines for protection against radiation $\ldots \ldots \ldots \ldots \ldots$

2 Background radiation levels for the northern New Jersey area . . . . . . . . . 9

3 Concentrations of radionuclides in soil at 19 Redstone Lane, Lodi, New Jerscy

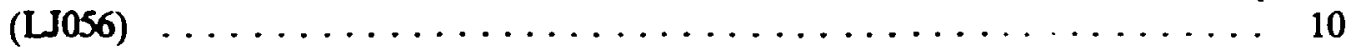




\section{ACKNOWLEDGMENTS}

Research for this project was sponsored by the Division of Facility and Site Decommissioning Projects, U.S. Department of Energy, under contract DE-AC05-840R21400 with Martin Marietta Energy Systems, Inc. The authors wish to acknowledge the support of J. E Baublitz Acting Director, Office of Remedial Action and Waste Technology, J. J. Fiore, Director, Division of Facility and Site Decommissioning Projects; and members of their staffs. The authors also appreciate the contributions of $\mathrm{J}$. L. Rich, S. W. Hawthorne, and L. J. Jeffers of the Publicaions Division; M. S. Uziel of the Environmental Remediation Group; D. A Roberts of the Measurement Applications and Development Group; E I Loy of Don Stone Associates; and B. S. Ellis, R. W. Doane, and J. A. Roberts, iormet employee of Martin Marietta Energy Systems, Inc. for participation in the collection, analyses, editing, and reporting of data for this survey. 


\begin{abstract}
Maywood Chemical Works (MCW) of Maywood, New Jersey, generated process wastes and residues associated with the production and refining of thorium and thorium compounds from monazite ores from 1916 to 1956 . MCW supplied rare earth metals and thorium compounds to the Atomic Eneryy Commission ard various other government agencies from the late 1940: to the mid-1950: Area residents used the sandlike waste from this thorium extraction process mixed with :ea and cocos leaves as mulch in their yards. Some of these contaminated wastes were als., ercded from the site into Lodi Brook At the request of the U.S. Department of Energy (DOE), a group from Oak Riage National Laboratory ecnducts investigative radislogical surveys of properties in the vicinity of MCW to determine whether a property is contaminated with radioactive residues, principally $20 \mathrm{Th}$, derived from the MCW site. The survey typically ircludes direct measurement of gamma radiation levels and soil sampling for radionuclide anatysea. The survey of this site, 19 Redstone Lane, Lodi, New Jersey (LJ056), was conducted during 1985 and 1986.

Results of the survey demonstrated no radionuclide concentrations in excess of the DOE Formerty Utilized Sites Remedial Action Program criteria The radionuclide distributions were not significantly different from normal background levels in the northern New Jersey area.
\end{abstract}




\section{RESULTS OF THE RADIOLOGICAL SURVEY AT 19 REDSTONE LANE, LODI, NEW JERSEY} $(\mathrm{LJ056})^{*}$

\section{INTRODUCTION}

From 1916 to 1956, process wastes and residues associated with the production and refining of thorium and thorium compounds from monazite ores were generated by the Mayuciod Chemical Works (MCW), Maywood, New Jersey. During the latter part of this period, MCW supplied rare earth metals and thorium compounds to various government agencies. In the 1940 and 1950 , MCW produced thorium and lithium, under contract, for the Atomic Energy Commission (AEC). These activities ceased in 1956, and, approxinuately three years later, the 30-acre real estate was purchased by the Stepan Company. The property is located at 100 Hunter Avenue in a highly developed area in Maywood and Rocbelle Part, Bergen County, New Jersey.

During the earty years of operation, MCW stored wastes and residues in low-lying areas west of the processing facilities. In the earty 1930, these areas were separated from the rest of the property by the construction of New Jersey State Highway 17. The Stepan property, the interim storage facility, and several vicinity properties have been designated for remedial action by the Department of Energy (DOE).

The waste produced by the thorium extraction process was a sandlike material containing residual amounts of thorium and its decay products, with smaller quantities of uranium and its decay products. During the years 1928 and 1944 to 1946, area residents used these process wastes mixed with tea and cocon leaves as mulch in their lawns and gardens. In addition, some of the contaminated wastes were aoparently erodod from the site into Lodi Brook and carried downstream.

Lodi Brook is a small stream flowing south from Maywood with its headwaters near the Stepan waste storage site. Approximately $150 \mathrm{ft}$ after passing under State Route 17, the stream has been diverted undergrounis through concrete or steel culverts until it merges with the Saddle River in Lodi, New Jersey. Only a small section near Interstate 80 remains uncovered. From the 1940 to the 1970 when the stream was being diverted underground, its course was altered several times. Some of these changes resulted in the movoment of contaminated soil to the surface of a few properties, where it is still in evidence. In other instances, the contaminated soil was covered over or mixed with clean fill, leaving no immediate evidence on the surface. Therefore, ropertie in question may be drilled in search of former streambed material, even in the abeence of surface contamination.

As a result of the Energy and Water Appropriations Act of Fiscal Year 1984, the property discussed in this report and properties in its vicinity contaminated with residues from the former MCW were included as a decontamination research and development project under the DOE Fur.terly (Itilized Site Remedial Action Program. As part of this project, DOE is conducing radiological surveys in the vicinity of the site to identify properties contaminated with residues derived from the MCW. The principal radionuclide of concem is thorium-232. The radiological surveys discuseed in this report are part of that

\footnotetext{
- The survey performed by members of the Meacurement Applications and Development Group of the Health and Safety Research Divisuon a Oak Ridge National Laboratory under DOE contract DF.ACOS. 84OR21400.
} 
effort and were conducted, at the request of DOE by members of the Measurement Applications and Development Group of the Oak Ridge National Laboratory.

A radiological survey of the private, residential property at 19 Redstone Lane, Lodi, New Jersey, was conducted during 1985 and 1986 . The survey and sampling of the ground surface were carried out on October 25, 1985, and the follow-up subsurface investigation was performed on Septenber 13, 1986.

\section{SURVEY METHODS}

The radiological survey of the property included: (1) a gamma scan of the entire property surface outdoors and (2) collection of soil samples. No indoor survey measurements were performed. The survey methods followed the basic plan outlined in a correspondence from W. D. Cottrell to A J. Whitman.' A comprehensive description of the survey methods and instrumentation has been presented in another report. ${ }^{2}$

Using a portable gamma scintillation meter, ranges of gamma exposure rates were recorded for areas of the property surface. Systematic soil samples were then obtained at randomly selected locations irrespective of the gamma exposure rates. In addition, biased soil samples were collected in areas of elevated gamma levels; hcwever, not all elevated areas were sampled. Measurements were usualty made and soil samples collected from depths of 0 to $15 \mathrm{~cm}$. The samples were analyzed for ${ }^{220} \mathrm{Ra}$, ${ }^{232} \mathrm{Th}$, and ${ }^{238} \mathrm{U}$ content.

To define the exient of possible subsurface oil contamination, auger holes were drilled to depths of approximately $23 \mathrm{~m}$. A plastic pipe was placed in each hole, and a NaI scintillation probe was lowered inside the pipe. The probe was encased in a lead shield with a borizontal row of collimating slits on the side. This collimation allows measurement of gamma radiation intensitics resulting from contamination within small fractions of the hole depth. Measurements were usually made at $15-$ or $30-\mathrm{cm}$ intervals. If the gamma reading in the bole were elevated, a soil sample was scraped from the wall of the auger hole at the point sbowing the highest gamma radiation level. The augar hole loggings were used to select locations where further soil sampling would be useful. A split-spoon sampler was used to collect subsurface samples at known depthe In some auger holes, a combination of split-spoon sampling and side-wall scraping was used to collect samples.

\section{SUR VEY RESULTS}

Applicable federal guidelines are summarized in Table $1 .^{3}$ The normal background radiation levels for the nortbern New Jersey area are presenred in Table $2^{4.5}$ These data are provided for comparison with survey results presented in this report All direct measurement results presented in this report are gross reating; background radiation levels have not been subtracted. Similarty, background concentrations have not been subtracted from radionuclide concentrations measured in soil samplea.

\section{Surface Gamma Radiation Le rels}

Gamma radiation levels measured during a gamma scan of the property surface are given in Fig 1. Gamma exposure rates over the major portion of the property ranged from 5 to $9 \mu \mathrm{Rh}$. No evidence of elevated gamma levels was found. 
Systematic Soil Samples

Systematic soil samples were taken from various locations on the property for radionuclide analyses. Locations of these samples $(S)$ are shown in Fig. 2 with results of laboratory analyses provided in Table 3. Concentrations of radium, thorium, and uranium in these samples were all below background kevels for the northern New Jersey area (Table 2).

\section{Auger Hole Soil Samples and Gamma Logging}

Varying thicknesces of subsurface soil were sampled from depths of 60 to $185 \mathrm{~cm}$ in auger boles (A) drilled at two separate locations indicated in Fig. 2 The results of analyses of these samples are given in Table 3. Concentrations of radium and thorium in these samples ranged from 0.64 to $28 \mathrm{pCi} / \mathrm{g}$ and 0.81 to $3.2 \mathrm{pCi} / \mathrm{g}$ respectively. Radionuclide concentrations in all auger samples were below DOE criteria (Table 1) for thorium.

Gamma logging was performed in each of the two auger boles to characterize and further define the extent of possible contamination. The logging technique used here is not radionuclide specific. However, logging data, in conjunction with soil analyzes data, may be used to estimate regions of elevated radionuclide concentrations in auger holes when compared with background levels for the area. Following a comparison of these data, it appears that any shielded scintillator readings of 1000 counts per minute (cpm) or greater generally indirate the presence of elevated concentrations of $20 \mathrm{Ra}$ and/or $272 \mathrm{Th}$. Data from the gamma profiles of the logged auger boles are graphically represented in Figs. 3 and 4. Reading in all auger holes were near or below $1000 \mathrm{cpm}$

\section{SIGNIFICANCE OF FINDINGS}

Measurements and results of soil sample analyses taken at 19 Redstone Lane indicate that the property cortains no significant radioactive contamination above normal background levets in this area. Radiological ascessments of soil samples from the site demonstrate no radionuclide concentrations in excess of applicable Federal guidelines. 


\section{REFERENCES}

1. W. D. Cottrell, ORNL, to A. J. Whitman, DOE/HQ, correspondence, "Radiological Survey of Private Properties in Lodi, New Jersey" (August 15, 1984).

2 T E Myrick, B. A. Berven, W. D. Cottrell, W. A Goldsmith, and F. F. Haywood, Procedures Manual for the ORNL Radiological Survey Activities (RASA) Program, Oak Ridge National Laboratory, ORNLTM-8600 (April 1987).

3. U.S. Department of Energy, Guidelines for Residual Radioactive Material at Formerty Utilized Sites Remedial Action Program and Remote Suplus Facilities Management Program Sites (Rev. 2, March 1987).

4. T E Myrick, B. A Berven, and F. F. Haywood, State Background Radiation Levels: Results of Measurements Taken During 1975-1979, Oak Ridge National Laboratory, ORNL/TM-7343 (November 1981). 
ORNL-DWG 89-10733

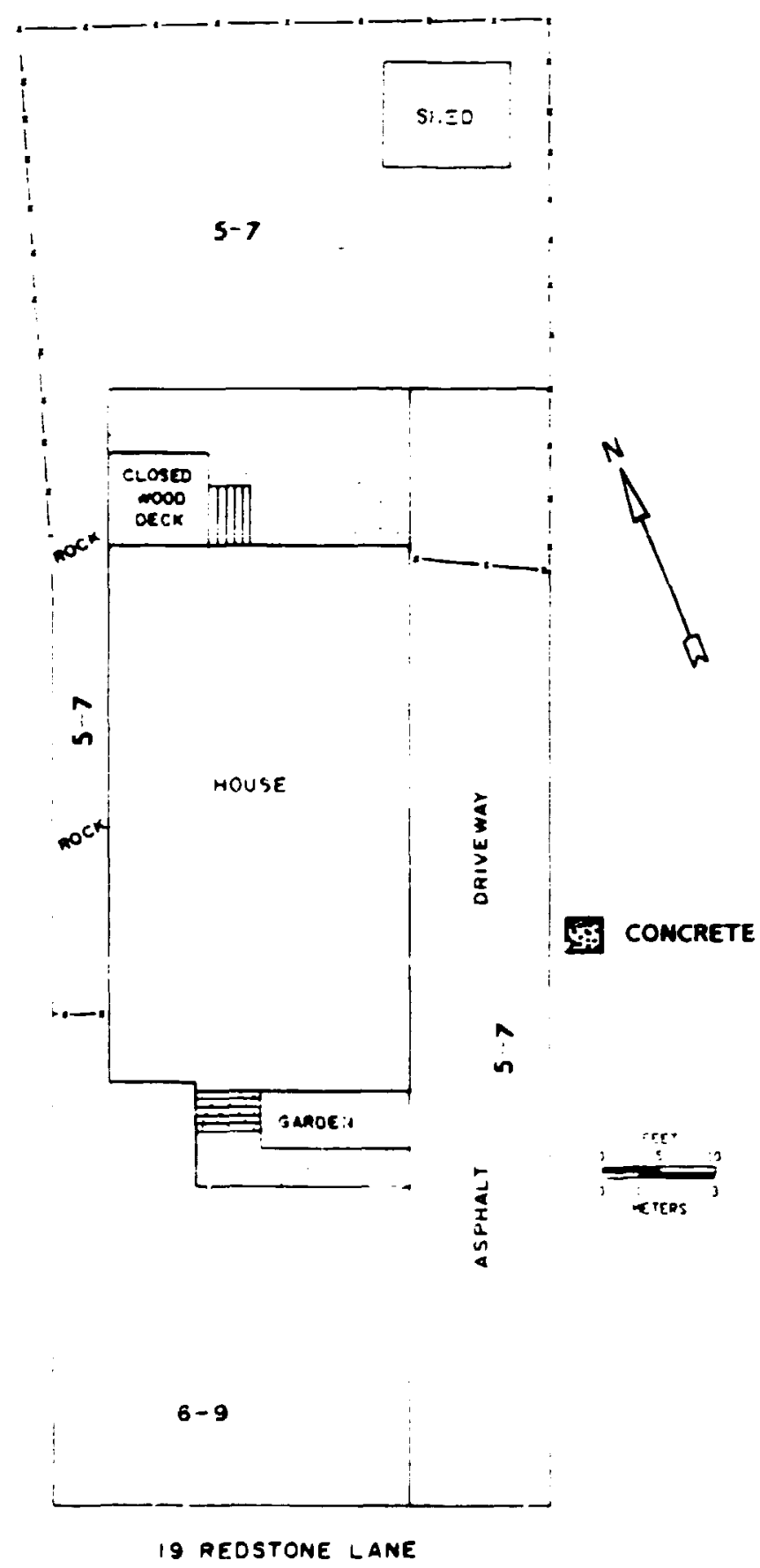

Fig. 1. Gamma radiation levels $(\mu R / \mathrm{h})$ measured on the surface at 19 Redstone Lane, Lodi, New Jersey (LJ056). 
ORNL-DWG $29-10734$

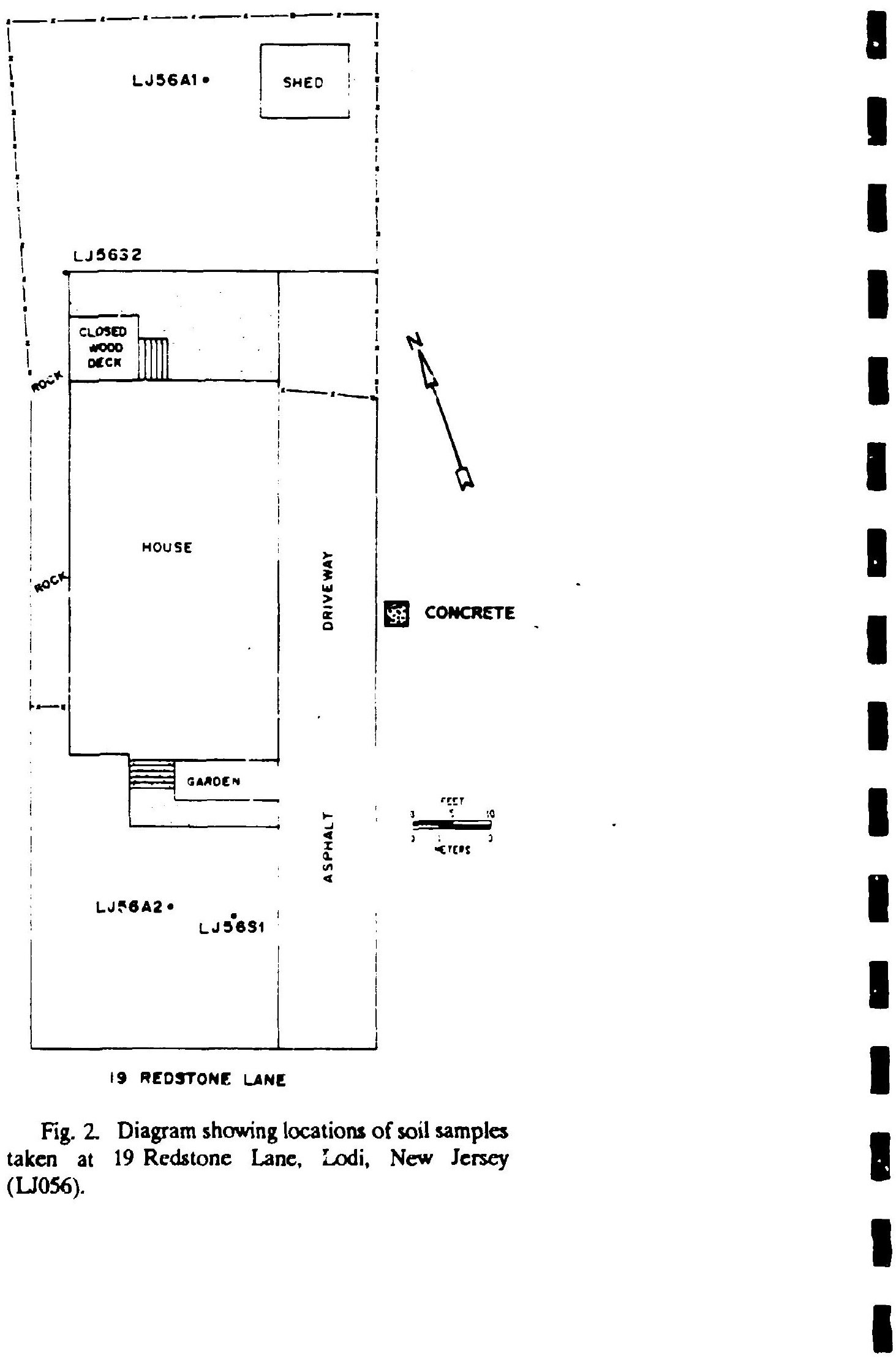


ORNL-OWG 89-10736

\section{ACTIUITY (1000 CFi)}

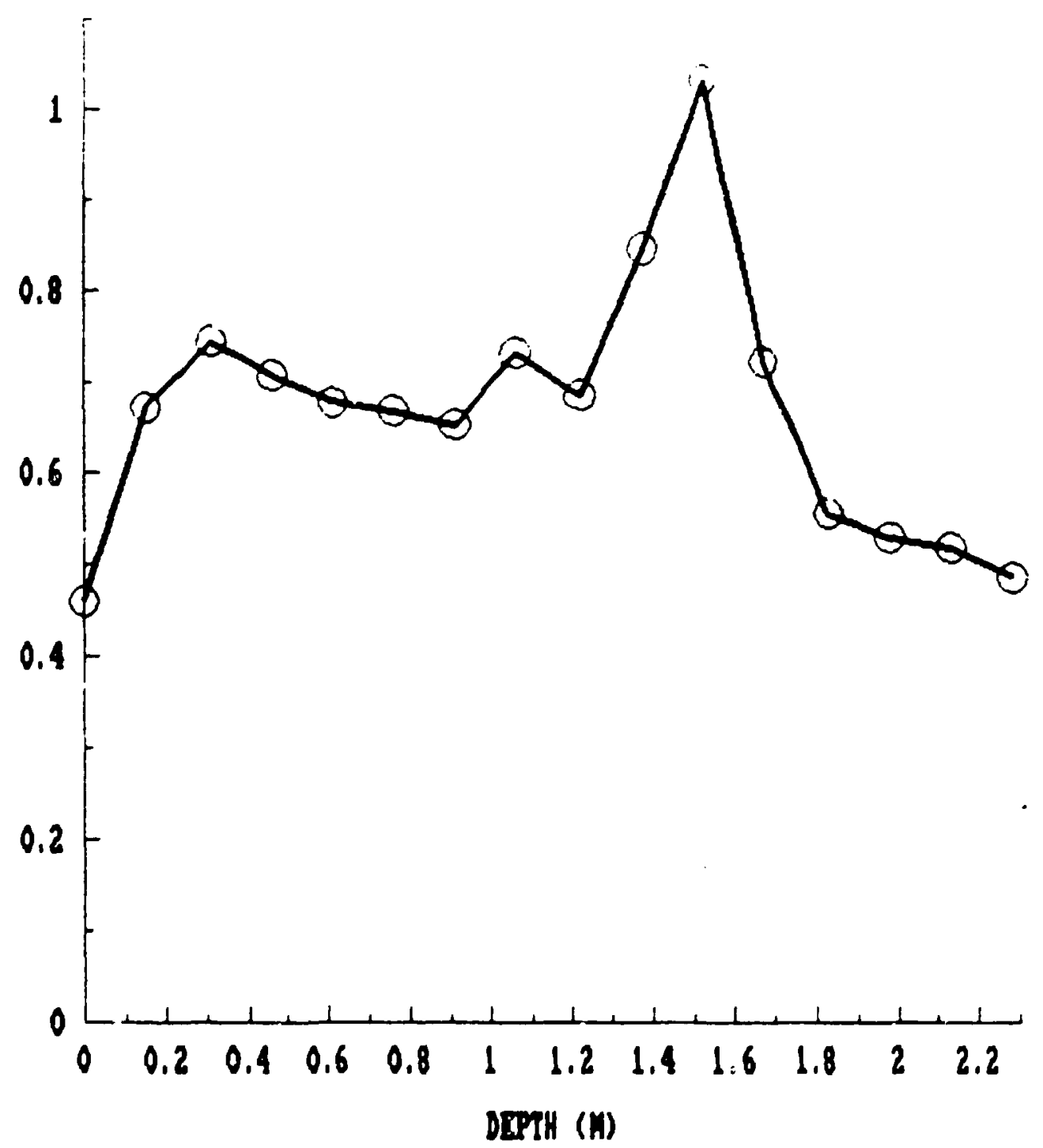

Fig. 3. Gamma nrofile for auger hole 1 (LJ056A1) at 19 Redstone Lane, Lodi, New Jerse): 
OANL-OWG 8910735

\section{ACTIUITY (1000 CPH)}

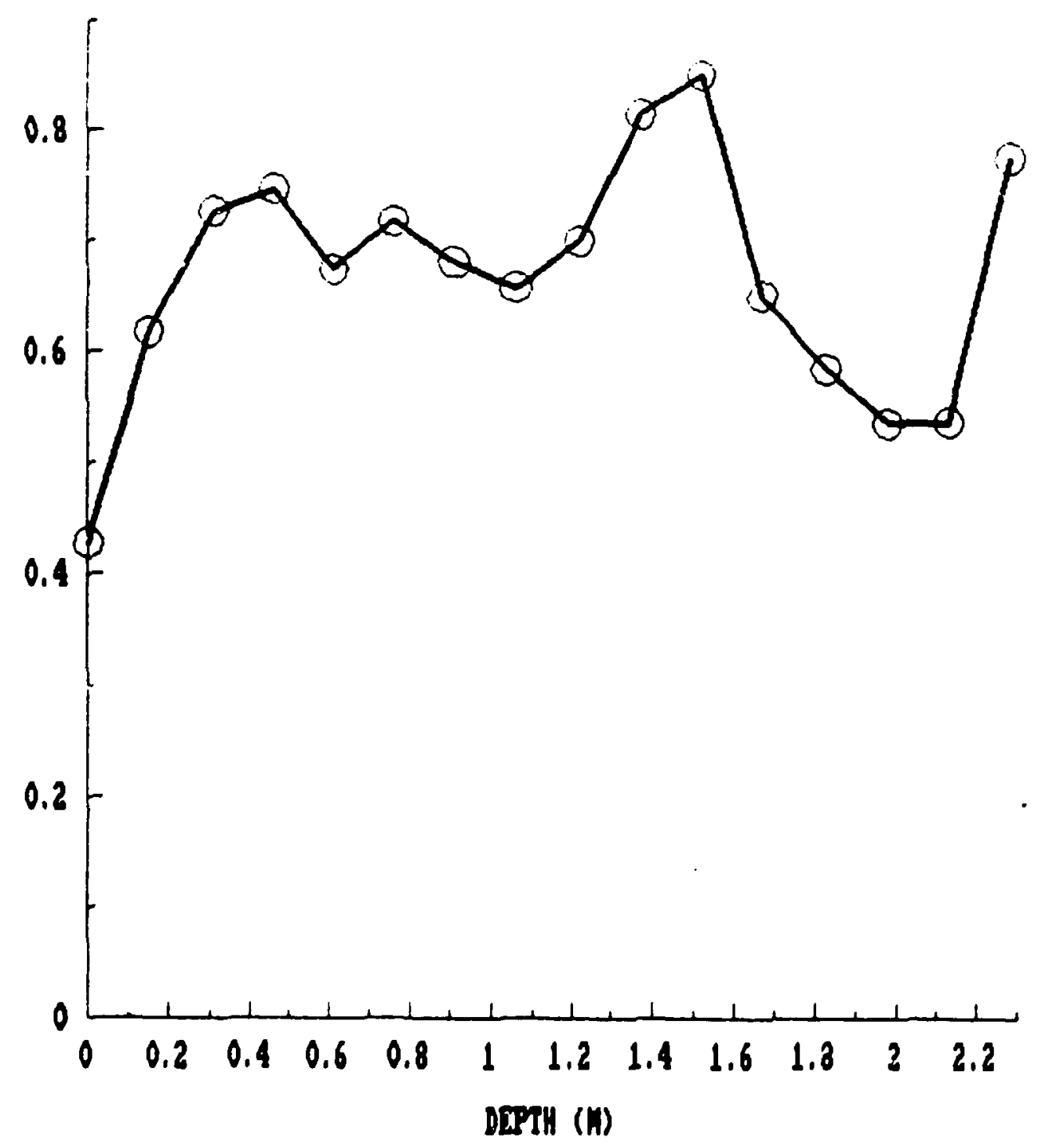

Fig. 4. Gamma profile for auger hole 2 (LJ056A2) at 19 Redstone Lane, Lodi, New Jersey. 
Table 1. Applicable guidelines for protection against radiation ${ }^{2}$

\begin{tabular}{|c|c|c|}
\hline Mode of exposure & Exposure conditions & Guideline value \\
\hline $\begin{array}{l}\text { Radionuclide concen- } \\
\text { trations in soil }\end{array}$ & $\begin{array}{l}\text { Maximum permissible con- } \\
\text { centration of the follow- } \\
\text { ing radionuclides in soil } \\
\text { above background levels } \\
\text { averaged over } 100 \mathrm{~m}^{2} \text { area } \\
232 \mathrm{Th} \\
230 \mathrm{Th} \\
228 \mathrm{Ra} \\
206 \mathrm{Ra}\end{array}$ & $\begin{array}{l}5 \mathrm{pCi} / \mathrm{g} \text { averaged over the first } \\
15-\mathrm{cm} \text { of soil below the sur- } \\
\text { face; } 15 \mathrm{pCi} / \mathrm{g} \text { when averaged } \\
\text { over } 15-\mathrm{cm} \text { thick soil layes } \\
\text { more than } 15 \mathrm{~cm} \text { below Ine } \\
\text { surface }\end{array}$ \\
\hline & $238 U$ & Derived (site specific) \\
\hline
\end{tabular}

'Reference 3.

Table 2. Background radiation levels for the northern New Jersey area

\begin{tabular}{|c|c|}
\hline $\begin{array}{l}\text { Type of radiation measurement } \\
\text { or sample }\end{array}$ & $\begin{array}{l}\text { Radiation level or } \\
\text { radionuclide concentration }\end{array}$ \\
\hline $\begin{array}{c}\text { Gamma exposure at } 1 \mathrm{~m} \text { above } \\
\text { ground surface }(\mu \mathrm{R} / \mathrm{h})\end{array}$ & $8^{6}$ \\
\hline \multicolumn{2}{|l|}{$\begin{array}{l}\text { Concentration of radionuclides } \\
\text { in soil }(\mathrm{pCi} / \mathrm{g})\end{array}$} \\
\hline $226 \mathrm{Ra}$ & 0.9 \\
\hline $232 \mathrm{Th}$ & 0.9 \\
\hline $238 \mathrm{U}$ & 0.9 \\
\hline \multicolumn{2}{|c|}{$\begin{array}{l}\text { These values represent an average of normal radionuclide } \\
\text { oncentrations in this part of the state. Actual values may } \\
\text { luctuate. } \\
\text { beference } 4 \text {. } \\
\text { 'Reference } 5 \text {. }\end{array}$} \\
\hline
\end{tabular}


Table 3. Concentrations of radionuclides in soil at 19 Redstone Lane, Lodi, New Jersey (LJ056)

\begin{tabular}{|c|c|c|c|c|}
\hline \multirow{2}{*}{ Sample' } & \multirow{2}{*}{$\begin{array}{r}\text { Depth } \\
(\mathrm{cm})\end{array}$} & \multicolumn{3}{|c|}{ Radionuclide concentration ( $\mathrm{pCi} / \mathrm{g}$ ) } \\
\hline & & ${ }^{206} \mathrm{Ra}^{0}$ & ${ }^{202} \mathrm{Th}^{*}$ & ${ }^{238} \mathrm{U}^{\mathrm{e}}$ \\
\hline \multicolumn{5}{|c|}{ Systematic samplest } \\
\hline $\begin{array}{l}\text { S1 } \\
\text { S2 }\end{array}$ & $\begin{array}{l}0-15 \\
0-15\end{array}$ & $\begin{array}{l}0.58 \pm 0.04 \\
0.65 \pm 0.08\end{array}$ & $\begin{array}{l}0.68 \pm 0.1 \\
0.78 \pm 0.3\end{array}$ & $\begin{array}{l}0.60 \\
0.70\end{array}$ \\
\hline \multicolumn{5}{|c|}{ Auger samples } \\
\hline A1A & $60-90$ & $0.64 \pm 0.2$ & $0.81 \pm 0.1$ & ' \\
\hline A1B & $120-150$ & $0.68 \pm 0.05$ & $0.86 \pm 0.09$ & 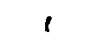 \\
\hline $\mathrm{AlC}$ & $150-185$ & $1.5 \pm 0.04$ & $3.2 \pm 0.04$ & ' \\
\hline $\mathrm{A} 2 \mathrm{~A}$ & $60-90$ & $0.68 \pm 0.06$ & $0.91 \pm 0.3$ & 1 \\
\hline $\mathrm{A} 2 \mathrm{~B}$ & $120-150$ & $1.0 \pm 0.04$ & $1.1 \pm 0.3$ & 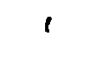 \\
\hline $\mathrm{A} 2 \mathrm{C}$ & $150-185$ & $28 \pm 0.2$ & $1.1 \pm 0.3$ & 1 \\
\hline
\end{tabular}

'Locations of soil samples are shown on Fig. 2

"Indicated counting error is at the $95 \%$ confidence level $( \pm 2 \sigma)$.

Total anatytical error of measurement results is less than $\pm 5 \%$ (95\% confidence level).

Systematic samples are taken at locations irrespective of gamma exposure rates.

-Auger samples are taken from holes drilled to further define the depth and exteni of radioactive material. Holes are drilled where the surface may or may not be contaminated.

'Sample was not analyzed for $\mathrm{U}$. 